\title{
The Evolution of India's Domestic Political Situation After Independence in the Eyes of Marginalized Groups
}

\author{
Gayathri Viswan K
}

\begin{abstract}
Post-colonisation India has grown significantly by producing itself as a powerful developing country at the global level. While the upward growth in economic terms is well appreciated, the degradation in the lives of neglected groups of society remains in injustice. The marginalised community of the country, mainly focusing on transgenders and Dalits, remain in darkness when the whole country shines brighter than the stars. After independence, India had gotten rid of many practices that stopped it from progressing, like Sati, and provided voting rights for everyone. But it is a saddening truth that the trans community in India only received voting rights within recent years. The constitution of India declares discrimination practices unacceptable. But there are still incidents in rural and urban areas where Dalit people are segregated from the other castes. Incidents of transgressions against transgenders and Dalits including moral policing and mob lynching remain unreported in many cases. Even when reported, justice is delayed or not provided at all. There are constant debates on the removal of reservations for marginalised communities from educational institutions and job postings. But the numbers have always shown that they remain under-represented. Transgenders do not even have reservations at any level. When the world looks up to India to learn from its unity in diversity, the marginalised remain marginalised.
\end{abstract}

Keywords: marginalised, transgender, Dalit, transgression, mob lynching

\section{Introduction}

\begin{abstract}
About the Author
Indian Author, actress, and political activist, Arundhati Roy (born on Nov 24, 1961) is known for always being vocal about various social and political issues within and outside the world of literature. Roy is well-recognized as an outspoken advocate of human rights in the Indian subcontinent. The Ministry of Utmost Happiness is considered to be one of her best comeback novels after her debut novel, The God of Small Things. The latter also won her the Man Booker Prize, making her the first Indian to do so.
\end{abstract}

\section{About the novel \\ The unquestionable literature treasure is a magical journey that gives an insight into the neglected lives of Indian society. The reader can gain a deep understanding of distinct but similar characters. The raw depiction of the marginalised community includes transgender, Dalits, and women. The story is set in the backdrop of the post-independence era. The chronicle of events which wounded India}

\section{Social aspects of the novel}

Anjum, formerly known as Aftab, left her parent's house at the age of fifteen to live at the Khwabgah, a home for transgenders like her. She was brought up a boy by her family but soon experienced the obvious physical changes. She was bullied by her classmates which made her hate her selves. She even ended up harming her body trying to hide every trace which showed hints of her masculinity. Anjum's parents are shown turning to every medical treatment available to "correct their son" and to erase off the cursed word, Hijra. Later, even when Anjum learns to embrace herself, society never lets her forget that she is "not normal". She raises an abandoned child Zainab, like her own daughter. But later when she again finds an abandoned baby on the streets, the crowd especially a leading politician present there starts mocking her. Aside from questioning her motherly love, they go to the extent of accusing the trans community of kidnapping children and converting them to one among them.

The novel leaves the reader with numerous thoughts questioning even the silliest of prejudice that the Indian society has towards transgenders. The mental trauma caused by the transgressions of moral policing to the trans community is never acknowledged. Even the basic human right is snatched from their lives. There is a daily fight to reassure their validity and struggles to try to prove themselves to the privileged and shameless people. The most disheartening incident from the novel was when some Hindu extremists group during the attacks in Gujarat stopped from killing Anjum because she was a Hijra. Killing a Hijra is believed to be bad luck. An old man who had accompanied her was murdered because he bought no good luck. When belief is treated more important than a person's life, humanity is dead and long forgotten. This is when society is in a dangerous and critical period.

Young India born after independence was seen with hope. But it was always a battlefield, a bloodshed. The partition started the war, the riot among the two communities in India. When the rest of India was celebrating liberty, the extremist groups from both countries were destroying themselves and each other. The political instability in India resulted in loss to many. But the worst affected is always the members of the marginalised community. Unfortunate events like the Gujarat riot and the social stigmas have left the community irrecoverably wounded. Saddam Hussain, an ally of Anjum is from the Dalit community. He was once arrested alongside his father for slaughtering a cow which was exaggerated and blown out of proportion. His father is later mob lynched to death. The uproar of the people for a few minutes costed a life. Anjum and Saddam expose how people of every religion and class are corrupted in one way or the other. India after independence is a revolution on mixed terms. There are people who are trying to top their beliefs and dreams to reach nirvana in their own way, to reach the ministry of utmost happiness. But when the paths 
collided, sparks happened which resulted in this wildfire of hatred, suppressing others low, and the marginalised even lower.

\section{Research Methodology}

The research methodology undertaken by the researcher is qualitative in nature. The researcher carried the analysis based on earlier texts, hearings and interviews related to the various social aspects of the novel. The various sources from which these were collected includes Jstor and other authentic sources online. The primary objective of the study is to discuss and elaborate on the key ingredients forming the backdrop of the story's plot. This includes the saddening realities of the society after independence of the country. Even if it has been years after attaining freedom, the study attempts to do a reality check on how far the community has come in eradicating the transgressions shown towards the marginalised communities like transgender and Dalits. The researcher tries to understand the distinct interpretations put forward by various other researchers and also makes a study on the relevant parts of the novel accordingly.

\section{Literature Review}

In the attempt learn about some major aspects of the novel, the researcher has referred various literature works written on the novel and the key subjects of the study. The transgender realities(Agoramoorthy \& Hsu, 2015) in the ancient period and the contemporary society has a distinct face. While the earlier conceptions were surrounding various Hindu myths, the present revolves more around the decisions of institutions like the court.Indian society as said has been changing for the good. The Indian law gave recognition to the transgender community.(National Legal Services Authority v. Union of India, 2014) They were recognised as the third gender of the society. Even though the judgement is seen faulty in the way it was implemented, it is still considered a major victory for the transgender community of India.Indian judiciary is slowly paving its way to ensure the rights of the LGBT community in India. Many prominent cases including this has been the evidence to this.(Narrain) Saisha Shinde, the famous fashion designer in the Bollywood industry while coming out on social media(Sen, 2020) shared her story on realising her orientation and coming out to her close ones who turned out to be supportive.

In the recent year, there has been a louder uproar around the world regarding the Black Lives Matter movement. Suraj Yengde, the founder of Dalit-Black Lives Matter symposium in an interview(Yengde, 2020) talks on how Dalit Live Movement is as important as the Black Lives Matter. He speaks on how the Indian social media has been speaking for the black people's lives but is silent on the atrocities happening against the Dalits of their very own country. Not just outside the community, the Dalit people themselves have taken into their hands to overcome the oppression.(Guru, 1995) The women of the community is actively fighting the patriarchal and casteist society. They speak on how violence against women like rape and sexual harassment has many factors causing them with caste being a very big factor.

\section{Analysis}

The novel is a masterpiece for being able to tell not just the story of the main character alone but also the side characters with short back stories and impactful dialogues. Anjum is the protagonist of the story. She is a transgender born in the body of a male. This forces her to live as a boy for former years of her life. The Indian society has shown hatred and indifference for the LGBTQI+ community throughout the decades. Even if the science and technology has reached the moon, the mindset of the people remains narrow and closed for the community. This is why it could be said that complete independence was never attainable for the community in India like other people of the society. They are still being forced to live a life filled with lie because of the thinking that, 'what will the people say'. This is the mindset that Anjum's parents showed when the got to know that their 'precious son' is not what they expected to be and is what they call a Hijra.In the introduction scene, Anjum has a conversation with her friend. She says that the God made the Hijras while trying to create the unhappiest creatures.

In the second chapter, Khwabgah we journey through the former years of Anjum's life as Aftab. Aftab's mother did not take it well when she got to know that his child is a Hijra. She goes to an extend of keeping it a secret from her very own husband. Later when Aftab's father got to know about this, they soon started looking for treatments as if being a Hijra is something to be treated. This is common misconception in the society. Even an educated doctor tries to help them to conceal this by sealing the girl- part. Bulling was common for Aftab from his classmates. No one is born with hatred. It is the kind of thoughts put into the children by the society that makes the think and act in a certain kind of way. The mental trauma that this puts the victims sometimes affect them the whole life. Aftab was called names like heshe at school. He hated having the deep voice of a man which he got during puberty which made him quit his singing classes even though he was very talented. The society should take an extra care and step to nurture and protect such little talents. One should never be caused to quit for being what they are. This chapter also briefs on the stories of other Hijras she meets at the Khwabgah which is later becomes Anjum's safe place. The media at point does cover Anjum's story but this was support they showed remained restricted to papers and screen as business. During the 2002 Gujarat riot, Anjum gets attacked along with an old man accompanying her. They are both Muslims which made it impossible for the man to escape death. But Anjum survives. She is left unharmed because she is a Hijra. In the beliefs of the attackers, harming a Hijra will bring bad luck to you. She escaped because she was butcher's luck. These are some shocking and traumatic moments of Anjum's life which changed her forever.

Mob lynching is increasing day by day. It is seen more common amongst the lower caste people like the Dalits. Saddam is a Dalit or as Anjum calls a Chamar, whose father died in such an unfortunate instance of mob lynching. His father got wrongly accused of killing a cow which is a religious figure for the upper caste people. He later got moblynched to death outside the police station. A crowd of 
worshippers killed a man and nobody stopped them, not even the police. He did not get justice because he was cowkiller and even worse a lower- caste person. Saddam had met Anjum while working in a mortuary. The doctors in the hospital would not touch the dead bodies coming in for post mortem in the fear of getting polluted. So the lower caste people, the untouchables like Saddam would do the work for them. This is the ugly caste system which continue to exist to the day. Even when many brushes of the presence of caste discrimination saying it does not exist in the current century, it still is very much engraved in every institution of the society. Even though Saddam only covers a smaller part of the novel compared to Anjum, the short yet powerful story he puts forth is very much impactful as much as Anjum's.

\section{Conclusion}

The novel shows how there are rarest of people who doesn't care about the gender or class of a person. Even in reality, the society has shown a progress but not enough to make the marginalised term removed from such minority communities or make them feel safe everywhere. Also we find that when one side has evolved forward, there are also people who have evolved extremely backwards in such thoughts. Claiming such thinking to be an opinion is wrong. Being transphobic or racist can never concluded as having an opinion. Their rights are just as important as any other people. It is human rights which is the most basic right of them all. Nobody has any right to take them away or business to interrupt or talk on the marginalised communities unless they themselves are a part of it. We also see how even when many shows support for such communities in talks like the media, the only people who actually turn up during any thick and thin is the community members themselves. This is something worth appreciating but at the same time an upsetting reality. You need not be the member of a community to be an ally to the people in it. The story of Anjum and Saddam is not any other fictional plots, it is representing and speaking for the people going through such realities of life. Arundhati Roy has done an excellent work in being observant enough to point out even the minute of such details directly or indirectly in the novel. This novel is an expression for all those Anjum and Saddam living amongst us but is being held captive and tortured in a cage invisible to the outer world. As the author says, the novel is an apt dedication to 'The Unconsoled'.

\section{References}

[1] Agoramoorthy, G., \& Hsu, M. J. (2015). Living on the Societal Edge: India's Transgender Realities. Journal of Religion and Health.

[2] Guru, G. (1995). Dalit Women Talk Diffrently. Economics and Political Weekly.

[3] Narrain, A. (n.d.). Vacillating between empathy and contempt: the Indian judiciary and LGBT rights. In Envisioining Global LGBT Rights.

[4] National Legal Services Authority v. Union of India (Supreme Court of India 2014).

[5] Sen, D. S. (2020). Swapnil Shinde is now Saisha Shinde! The day I wore my first heels and bra, everything changed.
[6] Yengde, S. (2020). Dalit and Black Solidarity: Interview with Suraj Yengde. 